\title{
Mandeville on charity schools: happiness, social order and the psychology of poverty
}

\author{
FRANCESCA PONGIGLIONE \\ University Vita-Salute San Raffaele \\ MIKKO TOLONEN \\ University of Helsinki
}

\begin{abstract}
Bernard Mandeville was not alone in criticising the charity school movement that had developed in Britain starting in late 1600; yet his Essay on charity and charity-schools is extremely provocative, especially as it regards the conditions of the poor. He criticises the selfish intentions and motives of charity schools, and inquires whether such schools are socially advantageous. This essay aims, first, to shed light on Mandeville's views on charity and charity schools, and demonstrate that such views are consistent with his moral thought. Second, this essay addresses problems inherent in Mandeville's views on how the working poor should be "managed"; what he proposes does not appear to guarantee (but rather puts at further risk) societal peace or the happiness of poor people.
\end{abstract}

Keywords: poverty, happiness, employment, necessity, mercantilism

\section{INTRODUCTION}

It used to be widely believed that Bernard Mandeville was not concerned about the poor. ${ }^{1}$ In truth, there is nothing to suggest that he was not a compassionate man either in his private life or in his profession as a

\footnotetext{
${ }^{1}$ It used to be that Mandeville's attitude toward the poor was described as "grim mercantilist", which depicted him as a harsh advocate of the utility of poverty (Wittkowsky 1943, 79; Heckscher 1956; Moss 1987). However, recent assessments of Mandeville's mercantilist background have taken a more nuanced view regarding his attitude towards the poor (Hurtado-Prieto 2006). For a balanced analysis of Mandeville's Augustinian and mercantilist background, see Dew (2013); Dew (2005); Brody Kramnick (1992). On the political aspects of poverty, see Gunn (1983). For a discussion about Mandeville's account of social progress, see Jack (1989).
} 
medical doctor. He worked with the poor and witnessed, first hand, the grim realities of life on the streets. Likewise, his work addressed problems facing marginalized peoples and offered solutions to those problems. For example, he adopted a strong stance against domestic violence towards women, which is discussed in Virgin unmasked (Mandeville 1999); he has used female characters in several of his dialogues; he even provided ideas on how to improve the conditions of working girls. ${ }^{2}$ In his medical practice he advocated for simple methods, and above all offered psychological help to the sick. He seemed to genuinely despise coffee-shop doctors who cashed in on quack pills. The reality of the living and working conditions of the poor, among other things, could have fostered his resentment of hypocrisy, which he set out to expose by means of paradoxical writing in his Fable of the bees (Mandeville 1924a) as well as in his treatment of Shaftesbury (who was seen to project his own privileged position onto the whole of human kind). ${ }^{3}$ Nevertheless, although Mandeville acquired many of his views about human nature through his involvement with the immigrant population and working class, it should be noted that this constituted only one context of his experiences. By contrast, the most puzzling of his works is his Essay on charity and charity-schools (Mandeville 1924b), which dealt with a much debated and delicate issue of the time: poor people and the so-called "charity schools" where impoverished children were sent to receive a basic education, as an alternative to early employment.

Mandeville was not alone in criticising the charity school movement that had developed in Britain since late seventeenth century, yet his Essay on charity and charity-schools seems extremely provocative with regard to the conditions of the poor. ${ }^{4}$ Indeed, there are many passages in the essay that convey an apparently unmotivated ruthlessness.

What can be said is that Mandeville seemed, generally, to make an effort to reconcile his views about such institutions with his moral thought; that is, his premises were motivated from the perspective of an objective morality (i.e., morality that is not concerned with appearance), in order to validate his arguments. Yet, his efforts to do so fell short at times: first, his attempt at reconciling his views with objective morality

\footnotetext{
${ }^{2}$ See Garrett.

${ }^{3}$ About Mandeville's relationship towards Shaftesbury, see Tolonen (2013, 32-34 and 68-69) and Tolonen (2015).

${ }^{4}$ For other contemporary discussions on charity schools, see for example, Defoe (1859), p. 14; Locke (1997); Berkeley (1948-1957, VI).
} 
was not convincing and thus not successful. Second, his portrayal of poor people was at odds with his own view of human nature, as if the poor belonged to a different species than human.

The aim of the paper is as follows: first, to shed light on Mandeville's views on charity and charity schools by going beyond the 'utility of poverty' discussion in order to show that such views are consistent with his general line thought: his criticisms of charity apply to the intentions that motivate charitable acts. In his texts Mandeville puts forward a view that claims that true morality is always and necessarily generated by self-denial, whereas charity and its "product"-i.e., the charity schoolsare not. Self-denial is used as a premise for a moral position, upon which he evaluated the acts of those who claimed to be charitable. The argument he put forward purports to show that charity schools are not motivated by genuine consideration of what is good for society, or for the poor themselves. Rather, charity schools put at risk societal peace and order, the wealth of the country and, ultimately, the happiness of the poor.

Second, the paper shifts focus in order to address the problems inherent in Mandeville's views of how the working poor should be "managed": what he proposes does not appear to guarantee (but rather puts at further risk) societal peace as well as the happiness of poor people. Mandeville's seemingly unconvincing and inconsistent arguments are analysed. Specific attention is given to his claim that the working poor ought to be kept in a state of poverty, and to his "portrait" of the poor, which portrays them as people with different passions and different needs-as if ultimately they have a different nature. An extensive discussion is dedicated to the claim that ignorance is the key to preserving poor people's happiness. It will subsequently be shown that Mandeville's claims are often contradictory and philosophically unsatisfying.

\section{MANDEVILLE'S CRITICISM OF CHARITY-SCHOOLS: HYPOCRISY OF MOTIVES, USEFULNESS OF RESULTS}

Mandeville's attack on charity schools was primarily meant as an attack on the hypocrisy of their founders, who pretended to be motivated by what is often referred to as the virtue of charity. At the same time, it could have reflected Mandeville's resentment of utopian projects built on self-deception with the tendency to do more harm than good. In moral terms, his analysis of charity in his Essay on charity and charity- 
schools was similar to his reflections on every other simulated virtue. A pure act of charity implies a form of self-denial, but Mandeville expressed extreme scepticism about identifying genuinely altruistic action. In fact, he argued that what is commonly regarded as charity tends to have nothing to do with virtue. The most common charitable actions arise from a mixture of pity and pride. Pity is a natural passion that arises upon the sight of someone suffering, especially when the senses perceive the pain of others. Helping to relieve suffering engenders a feeling of pride (Mandeville 1924b, 258). Vanity also plays a role in motivating charitable actions: people simulate charity in order to gain a good reputation $(1924 b, 261)$. Mandeville mentions the case of John Radcliffe, a rich doctor who ignored his immediate family and left a substantial part of his fortune to the University of Oxford, where he knew he would be remembered long after his death (1924b, 261). People are also disposed to donate goods to the poor to ensure deliverance from their sins. This kind of charity, which is motivated by selfish concerns, is hypocritical.

Mandeville criticised insincere charity, arguing against the hypocrisy charity schools: they are the consequence of human passions, not pure benevolence or altruism (1924b, 285). What disturbed him most is the hypocrisy that leads to their construction and the universal enthusiasm for them. However, a simple consideration of human nature would explain why the majority of people are so fond of charity schools: they give their supporters an opportunity to feel morally superior, offering redemption for their sins (1924b, 279). People will, of course, claim that the pleasure they experience in contributing to the common good motivated them, but once again, their alleged motives are very different from their real ones. According to Mandeville, "No Habit or Quality is more easily acquir'd than Hypocrisy, nor anything sooner learn'd than to deny the Sentiments of our Hearts and the Principle we act from" (1924b, 281). Moreover, a stronger reason for criticism, in addition to the motives discussed above, is that charity schools are not socially beneficial; they may even be detrimental to civil society.

\section{Risks raised by charity schools: crime, unemployment, unhappiness}

Mandeville began by analysing the outcomes of charity schools from the perspective of public interest. Referring to the social order, he argued that, despite what their supporters claim the schools do not reduce the number of criminals, and thus he downplayed the relationship between 
ignorance and crime. There were other reasons why thefts, burglaries, and murders were committed, the prime example being that the laws were not strict enough and that it was too easy to escape punishment. If the justice system were more severe, there would be far fewer criminals because the fear of punishment would deter them (Mandeville 1924b, 273). Charity schools might have even contributed to criminality, as Mandeville was convinced that another primary cause of crime is "the habit of Sloth, Idleness and strong Aversion to Labour and Assiduity" (1924b, 274), which charity schools may have encouraged, concluding that "it is not the want of Reading and Writing, but the concurrence and a complication of more substantial Evils that are the perpetual Nursery of abandoned Profligates in great and opulent Nations" (1924b, 275).

Mandeville also extensively analysed the outcomes of charity schools for their supposed beneficiaries-poor people. Again, he was not satisfied with what such schools achieved, which he summarised in two words: unemployment and unhappiness. The education in charity schools failed to achieve the main objective of every genuine educational institution: to help children find jobs after they finish their schooling. Mandeville was a strong supporter of practical education that directed one toward a specific line of work, while he was against the kind of non-tangible education given in charity schools, which did not teach any competence and risked to produce a generation of young adults who cannot find a job and consequently a decent position in society, and end up begging.

Mandeville's attack on what he considered to be unnecessary education of poor children is primarily pragmatic:

Reading, writing and arithmetick, are very necessary to those, whose business require such qualifications, but where people's livelihood has no dependence on these arts, they are very pernicious to the poor, who are forc'd to get their daily bread by their daily labour (1924b, 288).

The kind of education provided by charity schools could instead encourage laziness, and it would be much better to teach poor children a job and to send them to work at as early an age as possible (1924b, 267).

Employment is a crucial issue for Mandeville. He argues that, when it comes to "the social design of promoting arts and sciences", the "principal aim" of these undertakings "is the Employment of the Poor" 
(Mandeville 1733, 43), and that, "Employments might be found out for most our Lame, and many that are unfit for hard Labour, as well as the Blind, as long as their Health and Strength would allow of it" (Mandeville 1924b, 267-268). Charity schools were simply not the right means to provide employment.

Another major problem for charity schools, in addition to unemployment and its consequent social exclusion, was unhappiness. Given the kind of education provided, the children of the poor became aware of the existence of "another world" in which low wages, good beer, and simple clothes are not enough. Mandeville's claim that poor people should be kept ignorant rests on the fact that "it is impossible, that any Creature should know the Want of what it can have no Idea of" (Mandeville 1733, 285). To some extent, those who have never experienced certain comforts, and do not have the faintest idea about them, cannot really desire them strongly, and thus, do not suffer as much from their absence: it is much easier for the poor to accept their condition if they have never known an easier or better life than it is for the rich to give up privileges and habits to which they are habituated. He argued that...

Hard Labour and the coarsest Diet are a proper Punishment to several kinds of Malefactors, but to impose either on those that have not been used and brought up to both is the greatest Cruelty, when there is no Crime you can charge them with (Mandeville 1924b, 288289), ...

and that since "Abundance of hard and dirty Labour is to be done [...] the things I called Hardships, neither seem nor are such to those who have been brought up to 'em, and know no better" (1924b, 311).

For this reason Mandeville believed that a farmer, who had always lived a simple life full of hard work in the countryside, will not suffer because he does not have silk clothes or elegant furniture. This idea resembles what is now called the "endowment effect"-i.e., having or enjoying something and then losing it brings about much more suffering than never having experienced or possessed it (Thaler 1980). For this reason, one who is used to a comfortable life would hardly accept to be deprived of it and to work hard, while one who has never experienced anything different will adapt to it easily. Mandeville was convinced that children who were educated at charity schools, having become used to study rather than to work, would not submit to hard 
labour; and further, without having proper alternatives, those children would end up unhappy and unemployed, and likely would engage in criminality.

\section{Mercantilist arguments}

It is evident that Mandeville's ideas for maintaining a rich and flourishing nation were influenced by his mercantilist background (see Furniss 1920, 117). He argues that, ...

[t]he surest Wealth consists in a Multitude of laborious Poor; for besides that they are the never-failing Nursery of Fleets and Armies, without them there could be no Enjoyment, and no Product of any Country could be valuable (Mandeville 1924b, 287).

His point was that the wealth of a nation depends upon the poor working class: a certain quantity of poor people is required to do work that no one (the rich) would do. For this reason, it is hypocritical to praise charity schools without acknowledging the need of a poor working class. As the wealth of a particular nation, according to Mandeville, depends partly upon the poor working class, it is hypocritical to praise supposed means to get rid of ignorant poor and at the same time to enjoy the benefits of having a lot of poor people willing to work hard. This kind of hypocrisy was prevalent among those people who complained about the dangers of vice, yet enjoyed all the "public benefits" that arise from it; similarly, the same hypocrisy was prevalent among people who complained about London's dirty, stinking streets, but whose wealth depended on the trade, commerce, and other activities that took place on the streets. These activities contributed not only to the chaos of the streets, but also to the wealth and opulence of the city (Mandeville 1924a, 12).

In addition to pragmatic considerations, Mandeville argued for the economic need to keep workers poor. He believed that by keeping wages low among the poor, England could be competitive on an international level as the price of manufactures could have been kept low as well. He suggests that the poor should be paid according to their productivity as opposed to receiving a set weekly or monthly wage. ${ }^{5}$ What a "labouring

\footnotetext{
${ }^{5}$ In the Fables part II he writes: "Lucre is the best Restorative in the World, in a literal Sense, and works upon the Spirits mechanically; for it is not only a Spur, that excites Men to labour, and makes them in love with it; but it likewise gives Relief in Weariness, and actually supports Men in all Fatigues and Difficulties. A Labourer of any sort, who
} 
man" needs is "a moderate quantity of money; for as too little will either dispirit or make him desperate, so too much will make him insolent and lazy" (Mandeville 1924b, 194). Further, "The Proportion of the Society is spoil'd [if] the Bulk of the Nation [does not] consist of Labouring Poor, that are unacquainted with every thing but their Work" (1924b, 302). He therefore suggested that the greater the number of people working for low wages in a nation, the richer it will become. This is clearly a mercantile claim.

Adam Smith, and later Karl Marx, specifically criticized the mercantilist paradox (supported by Mandeville) that what makes a nation rich is its number of working poor. Marx pointed out that not only does having a multitude of poor people prohibit a nation from becoming rich, but that it is also dangerous as it puts social order at risk (Marx 1964, 643).

\section{UNCONVINCING ARGUMENTS AND INCONSISTENCIES}

Thus far the focus of this paper has been on Mandeville's views about charity schools. The aim has been to identify consistent arguments within his work and with the shared opinion of his time. However, most of what Mandeville wrote in his essay Charity-schools seems much less reasonable and not 'Mandevillian' at all. Rather, it reads as if he wanted to prove his point about the uselessness and perniciousness of charity schools, and cared less whether his arguments were theoretically suspect. It appears that he did not attempt to reconcile his views on charity schools with his other, perhaps more profound, views on human nature.

\section{A perennial state of necessity: incompatible with human passions, dangerous for social order?}

When Mandeville argues that workers need to be kept poor, his primary reason is the economic consideration examined above. He provided, however, a secondary reason-viz., that workers should be kept poor so that they find it necessary to work:

The absolute necessity all stand in for Victuals and Drink, and in cold Climates for Clothes and Lodging, makes them submit to any thing that can be bore with. If no body did Want no body would

is paid in proportion to his Diligence, can do more work than another, who is paid by the Day or the Week, and has standing Wages" (Mandeville 1733). 
work, but the greatest Hardships are look'd upon as solid Pleasures, when they keep a Man from Starving (Mandeville 1924b, 287).

In order to preserve this condition of necessity, wages have to be kept low: "Who, if by four Days Labour in a Week they can maintain themselves, will hardly be persuaded to work the fifth; [...] what reason have we to think that they would ever work, unless they were oblig'd to it by immediate Necessity?" (Mandeville 1924a, 192). This is why "the poor should be kept strictly to work, and that it was prudence to relieve their wants, but folly to cure them" (1924a, 248). Necessity thus seems to be the only way to force people to accept a life of sacrifice; furthermore, the working poor should "condescend" to accept an existence of hard work and deprivation. ${ }^{6}$

Such claims appear to be at odds with the common understanding of Mandeville's theory of human nature. ${ }^{7}$ For instance, one of the dominant human characteristics he emphasises is "the desire for more", to fulfil needs, and to satisfy appetites; this cannot, it seems, be reconciled with voluntary and compliant submission to unending toil. Even when he discusses the rational ability of humans to govern their passions, ${ }^{8}$ he insists that what all humans ultimately seek is the satisfaction of their desires: "All Human Creatures are sway'd and wholly govern'd by their Passions, whatever fine Notions we may flatter our Selves with" (Mandeville 1732, 31).

Mandeville seems to believe that humans seek satisfaction in every activity because they are dominated by passions, and that "all Passions center in Self-Love" (Mandeville 1924a, 75). Self-love is more than an instinct to preserve oneself. It can be seen to include the desire to be praised, and plays therefore a large role in governing human interaction (see Hjort 1991). In the Fable's Part I, self-love shares much in common

\footnotetext{
6 "It is impossible that a Society can long subsist, and suffer many of its Members to live in Idleness, and enjoy all the Ease and Pleasure they can invent, without having at the same time great Multitudes of People that to make good this Defect will condescend to be quite the reverse" (Mandeville 1924b, 286).

7 It should be emphasised that it is not altogether clear if we can talk about Mandeville's having a single, unfied, theory of human nature, even if this discussion is not the scope of this essay. One option for dealing with the apparent inconsistency is to accept that there is a lack of coherence in Mandeville's writings that would give us reason to discuss him as a theorist of human nature (or a philosopher as such). This is implicitly assumed by many philosophers today.

8 "Even those who act suitably to their Knowledge, and strictly follow the Dictates of their Reason, are not less compell'd so to do by some Passion or other, that sets them to Work, than others, who bid Defiance and act contrary to Both, and whom we call Slaves to their Passions" (Mandeville 1732, 31).
} 
with pride (though, in Part II of the Fable, Mandeville distinguishes it from self-liking, which is a more refined passion) (Lovejoy 1971, 171; Dickey 1990, 399; Tolonen 2013, 84-95). Mandeville believed that all humans possess pride (even the working poor). He states:

Pride is that Natural Faculty by which every Mortal that has any Understanding over-values, and imagines better Things of himself than any impartial Judge, thoroughly acquainted with all his Qualities and Circumstances, could allow him. We are possess'd of no other Quality so beneficial to Society, and so necessary to render it wealthy and flourishing as this (Mandeville 1924a, 124).

Mandeville seemed to suggest that every human being has a desire to improve his own condition, and that this desire is the driver of human action. In Remark 'M', Mandeville does not appear to exclude anyone from the domain of this passion, not even simple workers:

We all look above our selves, and, as fast as we can, strive to imitate those, that some way or other are superior to us. The poorest Labourer's Wife in the Parish, who scorns to wear a strong wholesom Frize, as she might, will half starve her self and her Husband to purchase a second-hand Gown and Petticoat, that cannot do her half the Service; because, forsooth, it is more genteel. The Weaver, the Shoemaker, the Tailor, the Barber, and every mean working Fellow, that can set up with little, has the Impudence with the first Money he gets, to Dress himself like a Tradesman of Substance (1924a, 129).

Passions, especially pride, seem to dominate all human actions. At first glance, there is no reason to believe that this does not apply to the working poor, who, unlike everyone else, work just for fulfilling their basic necessities. It is indeed true that Mandeville contemplates the possibility that people give up (some of) their passions at some point; but those who suppress their desires have other passion-driven aims instead. This led him to conclude that: "it is unreasonable to expect, that others should serve us for nothing" (Mandeville 1733, 349). Though, he never mentions the possibility that people voluntarily give up personal aspirations without hope for reward. His assumption about the innateness of pride permitted him to suggest that humans tend to value luxury over pleasure: the desire to possess things and to be admired will lead people to accept other deprivations. For example, women who want to look thinner and to fit in smaller clothes will deprive themselves of food (Mandeville 1924a). 
If we consider that all human beings are ruled by passions, it seems quite unfair to suppose that persons will submit to hard work without reward (other than having basic needs met), and also dangerous for the maintenance of social order. Yet, elsewhere, Mandeville has expressed scepticism about the possibility that human passions can be subdued and even claims that it could be dangerous for social order. Most of these reflections concern the political dimension of social order: Mandeville defended the principle of liberty against the tyranny of absolute government. This was based on his assumption about human nature, according to which, every kind of forced submission is ultimately dangerous for the socio-political order. The way to build a peaceful society is not through the exercise of sovereign power, as it is impossible to control humans by force alone (1924a, 42). An obvious example of this is slavery: slaves cannot be trusted and will always try to rebel against their captors (Mandeville 1987, 307). Here Mandeville seems to be making a more general point beyond the mere idea of a government exercising power over its subjects. The point is that human nature cannot easily be modified, and that passions cannot easily be suffocated. Accordingly, those in power should not underestimate the power of human passions, and should not assume that they can be easily suppressed. In The Fable's Part II he states that,

There is great Difference between being submissive, and being governable; for he who barely submits to another, only embraces what he dislikes, to shun what he dislikes more; But to be governable, implies an Endeavour to please, and a Willingness to exert ourselves in behalf of the Person that governs. [...] Therefore a Creature is then truly governable, when, reconcil'd to Submission, it has learn'd to construe his Servitude to his own Advantage; and rests satisfy'd with the Account it finds for itself, in the Labour it performs for others (Mandeville 1733, 184).

Although the context of these claims is the maintenance of political order rather than the working condition of labourers, the subject is the same-it deals with the human passions. In the former context (the social/political order) Mandeville advises politicians not to assume that humans can be subdued by force alone because their passions are not easily suppressed. By contrast, with regard to labourers, the only way to make them accept deprivation and hard living conditions is to inculcate the necessity of working. 
Nevertheless, Mandeville did not seem to consider fully that the ambitions and desires of poor people cannot be suppressed for long without threatening societal peace and order. Humans will never willingly submit to the will of others; at some point they will try to rebel. This was apparently clear to Mandeville concerning political issues. But, that the submission of poor people is just as likely to lead to unstable social conditions should have been clearer to him.

\section{Mandeville's portrait of the poor: ignorant and happy?}

It is not obvious, then, why it can't be assumed that the working poor would labour to earn more money, to achieve a comfortable lifestyle, and to improve their overall condition-this is what people typically do. Mandeville might have seen this objection and tried to respond to it, but the arguments he employs are problematic because of their inconsistency with his general line of thought.

The first argument goes as follows: when Mandeville talks about pride, he claims that it is a faculty that belongs to "every Mortal that has any Understanding". So perhaps his intuition was that without such "understanding" people would not display any signs of pride. Thus, if the working poor were kept away from charity schools (as sources of understanding), they would not become victims of this passion. It was for this reason that Mandeville stated that workers ought to be kept ignorant. He insisted that such ignorance guarantees a form of happiness that is possible only among the uneducated, and subsequently portrayed them in a way that closely resembles his idea of a savage in the state of nature. However, his attempt to prove that poor and ignorant people bound to hard work can be happy is not convincing and suffers from many inconsistencies.

Mandeville was probably aware of how untenable his position was, and for this reason added the provision of ignorance:

To make the Society happy and People easy under the meanest Circumstances, it is requisite that great Numbers of them should be Ignorant as well as Poor. Knowledge both enlarges and multiplies our Desires, and the fewer things a Man wishes for, the more easily his Necessities may be supply'd (Mandeville 1924b, 277-278).

Mandeville criticized charity schools as a source of knowledge since the more a man "knows" the less he is likely to accept a life of deprivation. The small amount of knowledge the working poor would 
gain at charity schools (such as the ability to read and write) would lead them to overestimate themselves (the same effect of pride), and thus to refuse to submit to hard work:

Those who spent a great part of their Youth in learning to Read, Write and Cypher, expect and not unjustly to be employ'd where those Qualifications may be of use to them; the Generality of them will look upon downright Labour with the utmost Contempt, I mean Labour perform'd in the Service of others in the lowest Station of Life, and for the meanest Consideration (1924b, 289).

Ignorance is therefore required for people to willingly submit to hard work. But it is not clear what Mandeville really meant when he talks about ignorance. Given that he wanted to support his claim about the harms of charity schools, it is possible that he simply referred to education. This is apparent in some passages, as he thinks that merely reading and writing can bring about damage. But, in other passages, he seems to refer to more than the kind of education one could learn at a charity school; it is a broader kind of knowledge, what he calls knowledge "of the world", and also "understanding". He writes that:

the Knowledge of the Working Poor should be confin'd within the Verge of their Occupations, and never extended (as to things visible) beyond what relates to their Calling. The more a Shepherd, a Plowman or any other Peasant knows of the World, and the things that are Foreign to his Labour or Employment, the less fit he'll be to go through the Fatigues and Hardships of it with Chearfulness and Content (1924b, 288).

Later in the text, when commenting on the necessity of the "inferiority" of the servants, he clarifies that he means "Inferiors not only in Riches and Quality, but likewise in Knowledge and Understanding. A Servant can have no unfeign'd Respect for his Master, as soon as he has Sense enough to find out that he serves a Fool" (1924b, 289).

Such arguments suggest that what Mandeville meant by keeping the poor ignorant went beyond the kind of education obtained in charity schools. The kind of ignorance that is required is not only lack of formal education, but also lack of "knowledge of the world", and lack of understanding. Yet such conditions would not be met simply by closing charity schools; they would require a different conception of human nature. 
Happiness is a central concept in Mandeville's prose. He had insisted that charity schools are likely to make the children of the poor unhappy given that, upon being educated, children will have glimpsed a life they could not achieve. In this context, unhappiness seems thus to be strongly connected to education, and this is perhaps why Mandeville professed that poor people should be kept ignorant. Mandeville devoted much attention to the happiness of the poor in order to prove that poor people could be happy despite being mired in their lowly condition, unable to ameliorate it with education. What needed to be clarified is the kind of happiness the poor could achieve, and whether it would be true happiness.

In medical and Epicurean terms, happiness is characterised as the absence of pain (be that mental or physical). For example, in the Fable of the bees Mandeville stated that, "those were the happiest, who felt the least pain" (Mandeville 1924a, 92). And, in the Preface to the Fable, Mandeville stated that, ...

if laying aside all worldly Greatness and Vain-Glory, I should be ask'd where I thought it was most probable thatMen might enjoy true Happiness, I would prefer a small peaceable Society, in which Men, neither envy'd nor esteem'd by Neighbours, should be contented to live upon the Natural Product of the Spot they inhabit (1924a, 12-13).

Thus, in order to be happy it would have been better to be frugal and moderate in one's passions: fewer wants and fewer passions lead to moderation and contentment.

Mandeville aimed to show that poor people were able to enjoy as much happiness as the rich because they had different needs and passions. The poor man is content drinking beer whereas the middleclass choice is more complex-e.g., he cannot decide between claret and port. The framework by which human nature is defined is fairly standard, but the poor and the rich differ with regard to the objects of their passions. Thus, even the poor could satisfy their passions, as they are described as

soon contented as to the necessaries of Life; such as are glad to take up with the coursest Manufacture in every thing they wear, and in their Diet have no other aim than to feed their Bodies when their Stomachs prompt them to eat, and with little regard to Taste or Relish, refuse no wholesome Nourishment that can be 
swallow'dwhen Men are Hungry, or ask any thing for their Thirst but to quench it (Mandeville 1924b, 286-287).

The key to understanding this desire mechanism is as follows: poor people's desires are different from those of the rich in that the objects of desire are more tangible. This is not to say that the poor and the rich are entirely different; but they do not appear to have similar desires (1924b, 311). ${ }^{9}$ This is a familiar argument put forward by all early modern writers, Christian and non-Christian alike: life's necessities among people in higher positions of society compared with those on the lower levels were assumed to be different.

Yet, it could be objected that, even if desires are different, the mechanism that drives the desire is the same, as Mandeville writes in the Remark 'M' (see above Mandeville 1924a, 129). This might be why Mandeville made the distinction between poor people and rich people, suggesting that they have ultimately different natures: "Excess of Vanity and hurtful Ambition are unknown among the Poor; they are seldom tainted with Avarice, with Irreligion never; and they have much less Opportunity of robbing the Publick than their Betters" (Mandeville 1733, 60 ). Poor people are content with what they have, so long as they ignore the pleasures and luxury of the rich. One may find "Union and Neighbourly Love, less Wickedness and Attachment to the World, more Content of Mind, more Innocence, Sincerity" among the hard working and the illiterate, and "Pride and Insolence, eternal Quarrels and Dissensions, Irreconcilable Hatreds, Strife, Envy, Calumny and other Vices destructive to mutual Concord" among university-educated scholars (Mandeville 1924b, 309).

The description of the poor Mandeville provided in Charity-schools resembles his description of man in the state of nature: the savage is a timorous rather than a voracious animal, characterised by "Innocence and Stupidity"; all the problems of the savage, as well as of the poor, arise from knowledge: "as his Knowledge increases, his Desires are enlarged (and consequently his Wants and Appetites are multiply'd)" (Mandeville 1924a, 205-206).

\footnotetext{
9 "Abundance of hard and dirty labour is to be done, and coarse living is to be complied with: where shall we find a better nursery for these necessities than the children of the poor? none certainly are nearer to it or fitter for it. Besides that the things I called hardships, neither seem nor are such to those who have been brought up to 'em, and know no better. There is not a more contented people among us, than those who work the hardest and are the least acquainted with the pomp and delicacies of the world".
} 
There are, nevertheless, some problems with this description of poor people. First, contentment and innocence are not drivers of action: "Content, the Bane of Industry, / Makes 'em admire their homely Store, / And neither seek nor covet more" (1924a, 35). If poor people are happy with their condition they have no reason to submit to hard work, and if they do it because they are guided by their passions and necessities, this is at odds with the idea of happiness and "contentment". If poor people work in order to satisfy their passions and necessities they are thus just like everyone else in the world, and the fact that the passions are less refined does not change the mechanism behind it.

It could be further argued that Mandeville actually had in mind a stoic idea of happiness, which meant that people could be happy in the worst conditions-i.e., hard work, low salary, simple food, no luxury. This is a recurrent theme in Mandeville's work. The Stoics indeed did not...

allow any Thing to be a real Good that was liable to be taken from them by others. They wisely consider'd the Instability of Fortune, and the Favour of Princes; the Vanity of Honour, and popular Applause; the Precariousness of Riches, and all earthly Possessions; and therefore placed true Happiness in the calm Serenity of a contented Mind free from Guilt and Ambition (1924a, 150).

This is not only found in the Stoics, as Mandeville states: "the generality of Wise Men that have liv'd ever since to this Day, agree with the Stoicks in the most material Points; as that there can be no true Felicity in what depends on Things perishable" (1924a, 151).

But, the working poor are excluded from such happiness. As such, the Stoics could be happy in spite of what befalls them, their force is in their mind: "the generality of Wise Men [...] agree with the Stoicks [...] that Knowledge, Temperance, Fortitude, Humility, and other Embellishments of the Mind are the most valuable Acquisitions" (1924a, 151). Thus, while the stoic is a wise man, the working poor is ignorant; while the stoic has knowledge on his side, the working poor has to be kept away from it at all costs; while the stoic commands his passions, the working poor has fewer passions, but does not command them-the necessity to satisfy at least some of them is what makes him work hard. The stoic is superior to others, the working poor needs to be inferior.

It could thus be stated that Mandeville's claim that poor people are happy does not hold. Even supposing that the poor are similar to savages, they could never enjoy the same happiness and contentment, 
as they are virtually enslaved by the rich, but lack the intellectual resources that would allow them to be happy even with such deprivations.

\section{CONCLUSION}

The aim in this paper was to explore Mandeville's highly criticised Essay on charity and charity-schools in order to establish what was valuable and reasonable therein, and what, even if less topical from a contemporary perspective, was problematic about his mercantilist background.

Despite some interesting elements, Mandeville's attempts to justify his views are not entirely convincing. Although it may well be that charity schools did not make poor people happy, and may have been detrimental to their wellbeing, the working conditions Mandeville proposed would have had no chance of generating a happy working class. On the other hand, the idea of teaching job skills instead of Latin, and focusing on employment rather than education makes some sense. The main problem is Mandeville's notion of necessity: In lacking basic needs and being dependent upon hard labour for low wages, the poor are more likely to experience civil unrest than "national happiness"Mandeville seemed to understand this given his explanation of the difference between submission and governability.

Yet, the idea of keeping the poor ignorant so as to subdue their passions and keep their happiness intact is inconsistent. This is for two reasons: Firstly, Mandeville's idea of ignorance does not seem to be confined to formal education, but rather to a general "knowledge of the world" and "understanding". But such forms of ignorance cannot be achieved by the mere abolition of charity schools. Rather, they require the presence of a different kind of human being, which he indeed theorizes about. However, the portrait of the poor person he conceives, which is very similar to his notion of the primitive savage, is again inconsistent with his ideas about happiness. Even the Stoic ideal of happiness cannot apply to the poor, since the Stoic's wisdom and superior knowledge allow him to feel happy despite his poor material conditions. Mandeville's ideal poor person, being ignorant and savagelike, cannot aspire to reach this kind of happiness.

In conclusion, Mandeville probably deserved the criticism his essay attracted, but more for the inner inconsistencies in his arguments than for his attack on the virtue of charity and charity schools. As he points 
out, such institutions were probably far from a good solution to the problem of poverty.

\section{REFERENCES}

Berkeley, George. 1948-1957 [1721]. An essay towards preventing the ruin of Great Britain, in The works of George Berkeley, bishop of Cloyne, ed. A.A. Luce and T. E. Jessop, 9 vols. London: Nelson.

Brody Kramnick, Jonathan. 1992. Unwilling to be short, or plain, in any thing concerning gain': Bernard Mandeville and the dialectic on charity. The Eighteenth Century: Theory \& Interpretation, 33 (2): 148-175.

Defoe, Daniel. 1859 [1704]. Giving alms no charity, and employing the poor a grievance to the nation, being an essay upon this great question, whether work-houses. Reprinted in A select collection of scarce and valuable economic tracts, ed. John Ramsay McCulloch. London: Harrison \& Sons.

Dew, Ben. 2005. Spurs to industry in Bernard Mandeville's Fable of the bees. British Journal for Eighteenth Century Studies, 28 (2): 151-166.

Dew, Ben. 2013. 'Damn'd to sythes and spades': labour and wealth creation in the writing of Bernard Mandeville. Intellectual History Review, 23 (2): 187-205.

Dickey, Lawrence. 1990. Pride, hypocrisy and civility. Critical Review, 4 (3): 387-431.

Furniss, Edgar Stephenson. 1920. The position of the laborer in a system of nationalism: A study in the labor theories of the later English mercantilists. Cambridge (MA): Riverside Press.

Garrett, Aaron. Women in the science of man. Working paper. www.academia.edu/9191324/Women_in_the_Science_of_Man (accessed January 2016).

Gunn, John Alexander Wilson. 1983. Mandeville: poverty, luxury and the Whig theory of government. In Beyond liberty and property: the process of self-recognition in eighteenth-century political thought. Montreal: McGill/Queen's University Press, 96109.

Heckscher, Eli Filip. 1956. Mercantilism New York: Macmillian Company.

Hjort, Anne Mette. 1991. Mandeville's ambivalent modernity. Modern Language Notes, 106 (5): 951-996.

Hurtado-Prieto, Jimena. 2006. The mercantilist foundations of 'Dr Mandeville's licentious system': Adam Smith on Bernard Mandeville. In New voices on Adam Smith, ed. Leonidas Montes and Eric Schliesser. London: Routledge, 247-270.

Jack, Malcom. 1989. Bernard Mandeville: the progress of public benefits. In Corruption and progress: the eighteenth-century debate. New York: AMS Press, 19-62.

Locke, John. 1997 [1697]. Draft of a presentation containing scheme of methods for the employment of the poor. In J. Locke, Political Essays, ed. Mark Goldie. Cambridge: Cambridge University Press.

Lovejoy, Arthur Oncken. 1961. Reflections on human nature. Baltimore: Johns Hopkins Press.

Mandeville, Bernard. 1924a [1724]. The fable of the bees: or, private vices, publick benefits, vol. I, ed. F.B. Kaye. Oxford: Clarendon Press. 
Mandeville, Bernard. 1924b [1724]. An essay on charity and charity schools. In The fable of the bees: or, private vices, publick benefits, vol I., ed. F.B. Kaye. Oxford: Clarendon Press.

Mandeville, Bernard. 1924c [1729]. The fable of the bees: or, private vices, publick benefits, vol. II, ed. F.B. Kaye Kaye. Oxford: Clarendon Press.

Mandeville, Bernard. 1971 [1732]. An enquiry into the origin of honour and the usefulness of Christianity in war, ed. Maurice Goldsmith. London: Fran Cass \& Co.

Mandeville, Bernard. 1987 [1729]. Free thoughts on religion, the church and national happiness, ed. B. Fabian and Irvin Primer. New York: Georg Olms Verlag.

Mandeville, Bernard. 1999 [1709-1710]. Essays in The female tattler. In By a society of ladies. Essays in The female tatler, ed. Maurice M. Goldsmith. Bristol: Thoemmes Press.

Marx, Karl. 1964 [1867]. Das Kapital. Kritik der politischen Ökonomie. Berlin: Dietz Verlag.

Moss, Laurence S. 1987. The subjectivist mercantilism of Bernard Mandeville. International Journal of Social Economics, 14 (3/4/5): 167-184.

Thaler, Richard. 1980. Toward a positive theory of consumer choice. Journal of Economic Behaviour and Organization, 1 (1): 39-60.

Tolonen, Mikko. 2013. Mandeville and Hume: anatomists of civil society. Oxford: Voltaire Foundation.

Tolonen, Mikko. 2015. Mandeville's answer to Berkeley. In Bernard De Mandeville's tropology of paradoxes morals, politics, economics, and therapy, ed. Edmundo Balsemao Pires and Joaquim Braga. Cham: Springer, 167-180.

Wittkowsky, George. 1943. Swift's modest proposal: the biography of an early Georgian pamphlet. Journal of the History of Ideas, 4: 75-104.

Francesca Pongiglione is assistant professor in moral philosophy at the University Vita-Salute San Raffaele, Milano, Italy.

Contact e-mail: <pongiglione.francesca@unisr.it>

Mikko Tolonen is professor of research on digital resources, Department of Modern Languages, University of Helsinki, Finland.

Contact e-mail: <mikko.tolonen@helsinki.fi> 